\title{
Mediterranean pine forests: management effects on carbon stocks
}

\author{
M. del Río, I. Barbeito, A. Bravo-Oviedo, R. Calama, I. Cañellas, C. Herrero, G. \\ Montero, D. Moreno-Fernández, R. Ruíz-Peinado, F. Bravo
}

\section{Introduction}

Carbon stored in forest systems is of great interest from a management point of view since, on the one hand, it is easily modified through silvilcultural practices (e.g., rotation length, thinning, etc.), while, on the other hand, it affects the mean lifespan of wood products. In the Mediterranean area, the role of forest as carbon sinks is particularly significant since usually ecosystem services provided by forests are frequently of greater value than their direct productions. Therefore, quantifying the carbon balance in forests is one of the main challenges if carbon fixation is to be considered amongst the objectives of forest management (Montero et al., 2005).

Aboveground biomass is usually estimated from forest inventories through biomass equations and biomass expansion factors at different spatial scales (e.g. Schroeder et al., 1997; Somogyi et al., 2007; Teobaldelli et al., 2009; Castedo-Dorado et al., 2012; Fang et al., 2014), whereas belowground biomass is often indirectly estimated from the aboveground biomass (Cairns et al., 1997; Mokany et al., 2006). Information is for other biomass components such as litter, dead organic matter or for soil carbon less abundant, because these elements are more difficult to measure and in many cases are more spatially variable than other components. However, our knowledge with regard to these components is notably enhanced over the last decade (e.g., Jandl et al., 2007; Woodall et al., 2008; Nave et al., 2010; Vesterdal et al., 2013).

A good understanding of the effect of forest management on the $\mathrm{C}$ cycle is crucial to integrate $\mathrm{C}$ storage into management strategies to mitigate climate change. The number of studies focussing on the effects of different management options on the $\mathrm{C}$ cycle and on C stocks has considerably increased (e.g., Campbell et al., 2009; Jurgensen et al., 2012; Powers et al., 2012; Ruíz-Peinado et al 2013, 2014). However, most studies focussed on particular sites, species and management regimes, lacking therefore a generalization of the impact of forest management on $\mathrm{C}$ sequestration. In this respect, available historical records are useful for analysing the effects of past management activities on $\mathrm{C}$ stocks while forest growth models can be helpful to estimate future $\mathrm{C}$ 
stocks under different management alternatives (Kolari et al., 2004; Balboa-Murias et al., 2006).

Furthermore, it is important to consider the impact global change on carbon storage, since there are ample evidences that changes in temperature and rainfall patterns observed during last decades are modifying forest growth rates (e.g. Pretzsch et al., 2014), including some in Mediterranean pine species (Andreu et al., 2007; MartínBenito et al., 2010a; Río et al., 2014). Most empirical growth and yield models are based on historical data under different climatic conditions than those forecasted and are not able to account for these possible climatic changes (Pretzsch, 2002). On the other hand, process based models are more versatile to account for a broader climatic conditions providing more reliable forecast of forest growth in a changing environment (Fontes et al., 2010). However, in some cases they are more suitable than empirical models for simulating management regimes.

Because of expected climate changes, long-term forest management in some Mediterranean areas will require the development of locally adapted sustainable forest management practices in the form of new silvicultural strategies to improve the resilience of the ecosystem and thus enable the continued provision of goods and services, including C storage (Scarascia-Mugnozza et al., 2000). These strategies should be based on historical analysis as well as on ecological knowledge in order to determine the extent to which the traditional forest management practices are adequate in the face of climate change. For example, the regulation of stand density through thinning was found to mitigate the drought effect on tree growth in Mediterranean pinewoods (MartínBenito et al., 2010b; Linares et al., 2009; Fernández-Uña et al., 2015).

In Mediterranean forests, species of the Pinus genus play a prominent role due to their widespread distribution and their ecological and socio-economical importance. Five species compose Mediterranean pine forests in Spain: Pinus halepensis Mill. (Aleppo pine), P. nigra Arn. (European black pine), P. pinea L. (stone pine), P. pinaster Ait. (Maritime pine) and P. sylvestris L. (Scots pine), and these cover more than 5 million ha as dominant species (Table 1), which means around $30 \%$ of the national forest area (Montero \& Serrada, 2013).

Table 1. Area of the Mediterranean pine forests in Spain by species according to Montero \& Serrada (2013) (in thousands of hectares).

\begin{tabular}{ccc}
\hline Species & Area & \%Total Forest area \\
\hline Pinus halepensis & 1,926 & $10.5 \%$ \\
Pinus pinaster & 1,373 & $7.5 \%$ \\
Pinus sylvestris & 1,184 & $6.5 \%$ \\
Pinus nigra & 625 & $3.4 \%$ \\
Pinus pinea & 390 & $2.1 \%$ \\
\hline Total & 5,498 & $30.0 \%$ \\
\hline
\end{tabular}


Because of the variability in forest typologies as well as in ecological and socioeconomic conditions, the management objectives in Mediterranean pinewoods are diverse, although protection is a key function of many pine forests. In this respect, pine species are those most frequently used in afforestation programmes and therefore, are of particular interest in terms of carbon sequestration.

Carbon accumulation in Spanish pine forests was over 249 million of Mg C in 2010, based on the second and third Spanish National Forest Inventories. The net annual amount of carbon sequestration through forest growth is around 5.8 million of $\mathrm{Mg} \mathrm{C}$ (Table 2). More than half of the total $\mathrm{C}$ stored in the pine forests is stored in Pinus pinaster and $P$. sylvestris forests.

Table 2. Carbon stocks in million of Mg C for the Mediterranean pine forests in Spain in 2010 based on Spanish National Forest Inventory

\begin{tabular}{ccc}
\hline Species & C stocks & $\begin{array}{c}\text { Net C sequestration } \\
\text { (net growth /year) }\end{array}$ \\
\hline Pinus halepensis & 46.14 & 1.36 \\
Pinus nigra & 42.46 & 1.01 \\
Pinus pinea & 17.25 & 0.50 \\
Pinus pinaster & 62.48 & 1.06 \\
Pinus sylvestris & 81.05 & 1.86 \\
\hline Total & 249.38 & 5.79 \\
\hline
\end{tabular}

In this chapter, estimates of carbon sequestration in Mediterranean pine forests from a number of studies and areas are presented along with associated information on how forest management influences this process. The information on forest carbon come from a number of sources including: i) carbon stock estimates under different management plans using a chronosequence trial in Pinus sylvestris forests; ii) simulations based on the process model 3-PG of the effect of different thinning regimes on Pinus pinaster biomass under a climate change scenario; iii) a comparison of the effect of different age structures in Pinus pinea forest using the PINEA growth model which includes the biomass allocated in cones and considers the different wood uses; and finally, iv) a model for estimating coarse woody debris.

\section{Effect of silviculture in carbon stocks in Scots pine forests}

The issue of carbon role in forests is one of the values that must be considered in order to decide how they should be managed. This value is known to vary greatly during stand development, and depends on the site and the type of management executed. Most carbon budget estimates are based on measurement from middle-aged or mature stand and little data are available for different stages of forest succession (Kolari et al., 2004). 
Previous studies in Mediterranean Scots pine forests suggest that the total amount of biomass varies greatly between woodlands because of site differences (Gracia et al., 2000). However, few studies focussed on forest management effects on those pinewoods (Ruiz-Peinado et al., 2013, 2014). In this section, we evaluated the relationship between carbon storage and different types of management over the length of the harvest rotation in Scots pine stands.

\section{$2.1 \quad$ Dataset}

A chronosequence trial was established in Pinar de Valsaín and Pinar de Navafría, managed Scots pine (Pinus sylvestris L.) forests located in the Central Mountain Range of Spain. In Valsaín, a group shelterwood system is applied, opening the stand gradually and allowing regeneration to take place naturally in a 40 years period. A moderate thinning regime is applied from the stem-exclusion stage onwards. The regeneration in Navafría forest is achieved using the uniform shelterwood system. Soil preparation is needed most of the times to achieve natural regeneration, although when this does not succeed, seedlings were planted. An intensive thinning regime is applied from the early stages.

Data were collected in six and five rectangular 0.5 ha permanent research plots that were installed in Valsaín and Navafría forests, respectively in 2001 (Table 3). These plots cover all the current age classes in both forests: from 1-120 years in Valsaín, where rotation length is 120 years, and from 1-100 years in Navafría, where rotation length is 100 years. In addition, in 2006 two additional plots were installed in the uppermost and lowermost limits of Scots pine growth spectrum, in uneven stands where few silvicultural interventions are carried out. In the lower limit $(1300 \mathrm{~m})$ Scots pine appears mixed with Pyrenean oak (Quercus pyrenaica Willd.) (plot V7, Table 3) while in the upper limit $(1800 \mathrm{~m})$ the pinewood is mixed with high mountain shrubs (mainly with Juniperus communis L. ssp alpina) (plot V8, Table 3). Since installation time, plots have been remeasured in 2006 and in 2011.

Table 3. Stand level variables in the experimental plots in Navafría forest (N1,N2,N3,N4 and N5) and in Valsaín (V1,V2,V3,V4,V5,V6,V7 and V8) at installation time: Plot size ( $m \times \mathrm{m}$ ); Age class (years); $N$, number of trees with $d b h \geq 10 \mathrm{~cm}$ and $d b h<10 \mathrm{~cm}$ per $h a ; d b h \geq 10 \mathrm{~cm}$ and $\mathrm{dbh}<10$ $\mathrm{cm}$, mean diameter at breast height $(\mathrm{cm})$ of trees with $\mathrm{dbh} \geq 10 \mathrm{~cm}$ and with $\mathrm{dbh}<10 \mathrm{~cm}$ respectively; $B A$, basal area $\left(\mathrm{m}^{2} / \mathrm{ha}\right) ; H \geq 10 \mathrm{~cm}$ and $H<10 \mathrm{~cm}$, mean height $(\mathrm{m})$ of trees with dbh $\geq$ $10 \mathrm{~cm}$ and with $\mathrm{dbh}<10 \mathrm{~cm}$ respectively.

\begin{tabular}{|c|c|c|c|c|c|c|c|c|c|}
\hline Plot & Plot size & Age class & $\begin{array}{l}\mathrm{N} \\
\geq 10 \mathrm{~cm}\end{array}$ & $\begin{array}{l}\mathrm{N} \\
<10 \mathrm{~cm}\end{array}$ & $\begin{array}{l}\mathrm{dbh} \\
\geq 10 \mathrm{~cm}\end{array}$ & $\begin{array}{l}\text { dbh } \\
<10 \mathrm{~cm}\end{array}$ & BA & $\begin{array}{l}\mathrm{H} \\
\geq 10 \mathrm{~cm}\end{array}$ & $\begin{array}{l}\mathrm{H} \\
<10 \mathrm{~cm}\end{array}$ \\
\hline \multicolumn{10}{|c|}{ Valsaín } \\
\hline V1 & $100 \times 50$ & $1-20$ & 458 & 8876 & 23.2 & 5.5 & 37.0 & 15.1 & 3.2 \\
\hline V2 & $85 \times 58.8$ & $21-40$ & 1484 & 1118 & 16.9 & 9.2 & 40.8 & 14.7 & 7.0 \\
\hline V3 & $100 \times 50$ & $41-60$ & 1296 & 26 & 20.8 & 9.2 & 48.3 & 16.4 & 11.9 \\
\hline V4 & $100 \times 50$ & $61-80$ & 686 & - & 30.5 & - & 53.3 & 23.5 & - \\
\hline
\end{tabular}




\begin{tabular}{llllllllll} 
V5 & $70.7 \times 70.7$ & $81-100$ & 552 & - & 34.7 & - & 54.2 & 22.1 & - \\
V6 & $100 \times 50$ & $101-120$ & 332 & - & 38.9 & - & 41.3 & 24.0 & - \\
V7 & $70.7 \times 70.7$ & Uneven & 526 & 1020 & 20.4 & 2.4 & 25.3 & 12.2 & 2.8 \\
V8 & $100 \times 50$ & Uneven & 488 & 330 & 22.0 & 4.8 & 22.7 & 10.7 & 4.0 \\
\hline Navafría & & & & & & & & \\
\hline N1 & $70.7 \times 70.7$ & $1-20$ & 810 & 4906 & 11.9 & 6.6 & 27.0 & 7.6 & 6.0 \\
N2 & $110 \times 45.5$ & $21-40$ & 2184 & 298 & 14.8 & 9.2 & 41.9 & 12.1 & 11.2 \\
N3 & $70.7 \times 70.7$ & $41-60$ & 680 & - & 32.9 & - & 60.6 & 22.0 & - \\
N4 & $70.7 \times 70.7$ & $61-80$ & 364 & - & 40.6 & - & 48.2 & 20.4 & - \\
N5 & $70.7 \times 70.7$ & $81-100$ & 304 & - & 42.5 & - & 44.2 & 22.1 & - \\
\hline
\end{tabular}

\section{$2.2 \quad$ Carbon estimations}

Dry biomass of the whole tree was estimated as a sum of their different fractions (stem, roots, branches and needles) using biomass models both for Scots pine (RuízPeinado et al., 2011) and for Pyrenean oak (Ruíz-Peinado et al., 2012). Using the values provided by Ibañez et al. (2002) the percentage of carbon in the biomass of $P$. sylvestris and $Q$. pyrenaica trees is $50.9 \%$ and $47.5 \%$ respectively.

We model the carbon stored over the stand age in each forest (excluding the uneven-aged plots of Valsaín) using a semiparametric approach through smooth penalized splines (Eilers \& Marx, 1996) employing B-spline basis due to their flexibility and ease of computation. The smooth splines are curves formed by joining together several loworder polynomials at specified locations known as knots (Jordan et al., 2008), with a penalty approach. The use of a low-rank smoother solves the computational problems of other approaches while the penalty approach relaxes the importance of the number and location of the knots. This model can be formulated within a linear mixed effects modelling framework and, therefore, it allows considering the temporal correlation among measurements taken in the same plot (Durbán et al., 2005). The model included the study site as linear predictor and fits a separate mean curve for each site by using a factor-by-curve interaction model to analyze the differences in the carbon stock among sites. In addition, we estimated the total carbon fixation rates ( $\mathrm{Mg} \mathrm{C} \mathrm{ha}{ }^{-1}$ ) in each plot and period by comparisons of inventories.

\subsection{Carbon stocks and fixation rates under the two management systems}

Concerning the even-aged stands, both forests followed a similar trend, reaching their maximum carbon dioxide fixation when stand density was more than 500 trees per ha and the mean diameter was larger than $30 \mathrm{~cm}$, which occurs at the class of 60-80 years in Navafría and 80-100 years in Valsaín. After this stage, when the stand is opened gradually to facilitate the establishment of the seedlings of the next serial stage, and the densities go to approximately 300 trees $^{-1}{ }^{-1}$ with mean dbh around $40 \mathrm{~cm}$, the carbon stocks decreases in both forests. Hence, the two last measurements in Navafría forest (95 and 100 years) correspond to the end of the regeneration fellings, the establishment of the regeneration and, therefore, the end of the rotation period. At 100-year-old, the total 
C stock (area below the curve) was slightly larger in Valsaín than in Navafría. On the other hand the storage rate was more gradual in Valsaín than in Navafría (Fig.1).

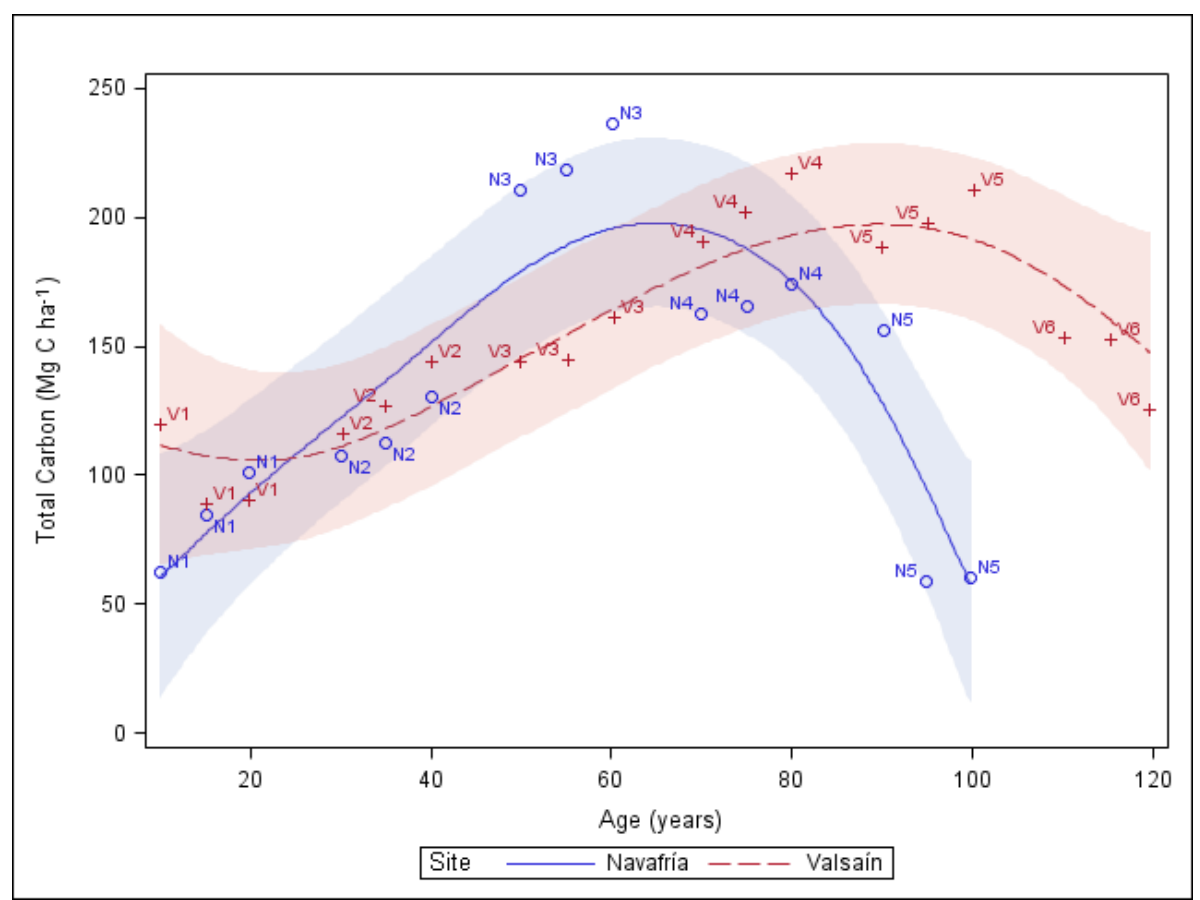

Figure 1. Estimated smooth trends of carbon stock in even-aged stands in solid lines and 95\% intervals of confidence in dashed lines. Blue colour $=$ Navafría, red colour= Valsaín. Blue circle $=$ observed values in Navafría and red crosses $=$ observed values in Valsaín.

The growth rates of $\mathrm{C}$ evolved different along the rotation period in Navafría than in Valsaín. In Navafría, we found a negative relationship between the growth rates and the plot age: the largest growth rates appeared in the youngest plots (average $\mathrm{C}=3.91 \mathrm{Mg}$ $\mathrm{C} \mathrm{ha}{ }^{-1} \mathrm{yr}^{-1}$ ) and decreased to the oldest plot (average $\mathrm{C}=0.54 \mathrm{Mg} \mathrm{C} \mathrm{ha}^{-1} \mathrm{yr}^{-1}$ ). In Valsaín, the growth rates increased from the youngest plot (average $\mathrm{C}=1.84 \mathrm{Mg} \mathrm{C} \mathrm{ha}^{-1} \mathrm{yr}^{-1}$ ) to V2 (average $\mathrm{C}=4.21 \mathrm{Mg} \mathrm{C} \mathrm{ha}^{-1} \mathrm{yr}^{-1}$ ), followed by a progressive decrease to the end of the rotation age (average $\mathrm{C}$ of $\mathrm{V} 6=1.78 \mathrm{Mg} \mathrm{C} \mathrm{ha}^{-1} \mathrm{yr}^{-1}$ ). The difference of regenerations systems and the thinning intensity might explain the different trends in growth rates in both forests. 


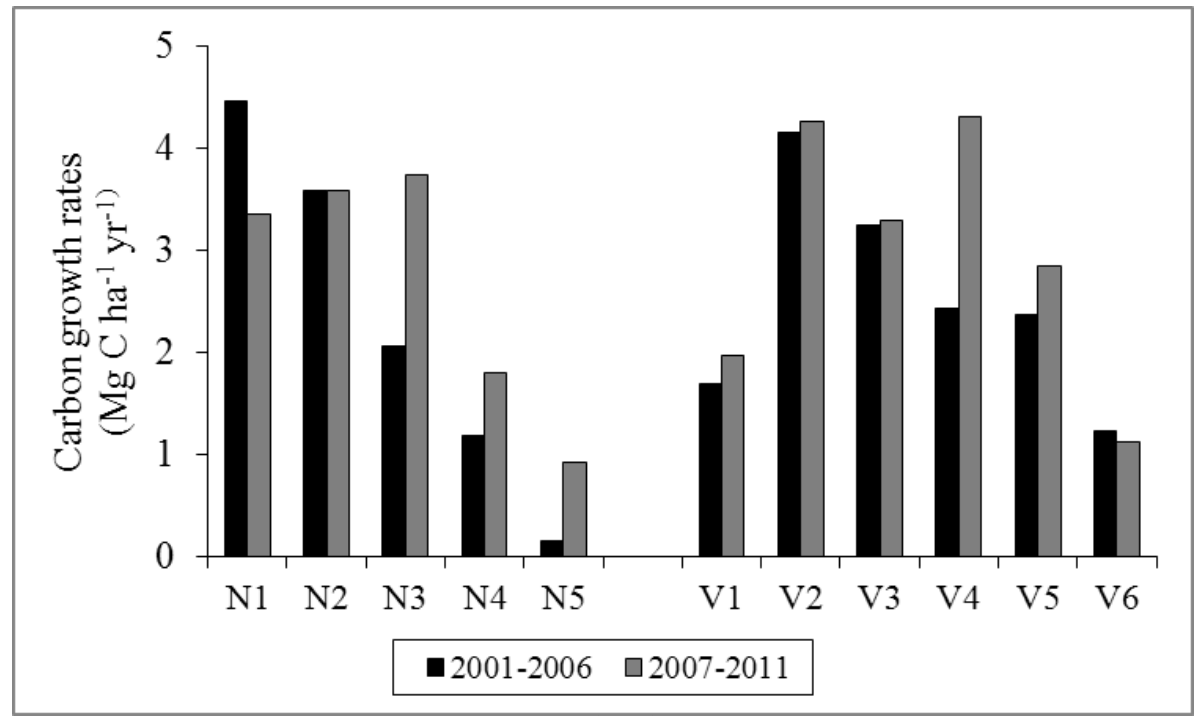

Figure 2. Growth rates of carbon (MgC $\left.\mathrm{ha}^{-1} \mathrm{yr}^{-1}\right)$ in even-aged stands in Navafría and Valsaín plots.

The carbon fixed for the uneven-aged plots located in Valsaín (V7: 82.23 Mg C ha ${ }^{-1}$ in 2006 and $90.52 \mathrm{Mg} \mathrm{C}^{-1}$ in 2011; V8: $63.26 \mathrm{Mg} \mathrm{C}^{-1}$ in 2006 and $80.91 \mathrm{Mg} \mathrm{C} \mathrm{ha}^{-1}$ in 2011) showed lower values than the rest of the even-aged plots studied in this forest (Fig. 1).

Low $\mathrm{C}$ accumulation values in the uneven-aged plot V8 can be explained by the small tree growth and the low density in high-altitude environments. In the mixed oak and pine stand, located at the lower limit of Scots pine distribution area, C accumulation values were found to be much lower than in any of the pinewood stands (except for N1 and the two last measurements in N5), also reflected in the smaller basal area in plot V7. Analyses of the carbon dioxide amounts previously conducted in the same geographical area (Bogino et al., 2006) also highlighted the difference between pure (482.63 $\mathrm{Mg} \mathrm{CO}_{2}$ $\mathrm{ha}^{-1}$ ) and mixed Scots pine stands (327.73 $\mathrm{Mg} \mathrm{CO}_{2} \mathrm{ha}^{-1}$ ). These differences might be due to the lower density of this plot and the much lower productivity rates of Quercus pyrenaica than Pinus sylvestris.

The figures obtained in this study are higher than the carbon stocks in Scots pine forests in Southern Finland, where values of $216 \mathrm{Mg} \mathrm{CO}_{2}$ ha $^{-1}$ for a 40 years old plot and $281 \mathrm{Mg} \mathrm{CO}_{2}$ ha $^{-1}$ for a 75 years old plot were found for similar density stands (Kolari et al., 2004). Concerning management alternatives, in a long-term Mediterranean thinning experiment Ruiz-Peinado et al. (2014) reported mean values that ranged from $128 \mathrm{Mg} \mathrm{C}$ $\mathrm{ha}^{-1}$ to $193 \mathrm{Mg} \mathrm{C} \mathrm{ha}^{-1}$ at the age of 52 years depending on the thinning treatment, with the greatest value in unthinned plots. This higher value in non-managed plots agrees with our finding that less intensive silviculture stores more carbon. Previous studies 
suggest that elongation of the rotation length increases the carbon stocks in Scots pine forests (Kaipainen et al., 2004; Liski et al., 2004). However, simulation studies suggested that very long rotations do not necessary maximize the carbon balance because the stand productivity declined due to the maximum annual increment has been exceeded (Jandl et al., 2007). Moreover, greater differences between the silvicultural systems applied in Valsaín and Navafría forests may arise if other components are taken into account (Montes \& Cañellas, 2006; Moreno-Fernández et al., 2015).

In addition to the disturbance caused by commercial harvesting, an increase in natural disturbances such as fires or plagues of insects might be expected as a result of climatic changes. The direct result of such disturbances is a decrease in the carbon stocks stored in vegetation, while the age-class distribution of the post-event forest tends towards the younger age classes which contain less carbon. Therefore, suitable strategies must be employed to mitigate these disturbances at stand level and to prevent forests from becoming sources of net carbon. Partial cover systems such as those currently employed in these forests, help to retain biomass and therefore contribute positively towards the proposed objective. Reducing the delay in regeneration and avoiding slash burns would also help to strengthen the role of these forests as carbon sinks. Another option, which might be feasible in mixed stands such as the one included in this study, would be to promote those species which have a higher carbon storage potential (e.g., in this case, Scots pine). However, for appropriate management decisions to be made, further research is required into the effects of climate change on these carbon sinks and the variation in carbon budgets over the course of the rotation (Vayreda et al., 2012).

\section{Mitigation through forest thinning in Mediterranean maritime pine afforestations}

Forest adaptation and mitigation have been addressed in the scientific agenda as two important measures to cope with climate change effects. Forest managers are now facing the need to assess the role of silvicultural practices in this context. The most important tending method available to silviculturists is thinning, a partial harvest that regulates the distribution of growing space so that standing trees may benefit in terms of competition, growth and health status (Smith et al., 1997). Favourable carbon sequestration occurs generally when low intensity thinning is applied (Balboa-Murias et al., 2006; Pohjola \& Valsta, 2006). Aboveground onsite carbon stock is correlated with stocking density (D’Amato et al., 2011) although when off-site carbon stock is considered the total carbon sequestration potential is usually found to increase with thinning (Ruiz-Peinado et al., 2013). However, the positive thinning effect in C sequestration may be modulated by species and the grade of the thinning that it should not exceed the 'marginal thinning degree' that cause a loss in volume production (Hamilton, 1981, Río et al., 2008).

An important question to be addressed it is if the currently applied thinning regimes will produce same results under changing climate conditions. This question may be 
answered using forest growth models that allow for variability in climate conditions such as hybrid models (Kimmins et al. 2010; Fontes et al. 2010). In this section we analyse thinning effects on Mediterranean maritime pine (Pinus pinaster Ait. ssp. mesogeensis) carbon stocks trough simulations from a forest growth model. The hybrid modeling approach allows us to simulate climate change effects on forest stands and, at the same time to assess the mitigation potential of thinning.

\subsection{Forest growth hybrid model approach}

We applied the 3-PG model (Landsberg \& Waring, 1997) to assess the effect of climate change and thinning on an afforested stand of Mediterranean maritime pine in south Spain. The 3-PG model is a canopy carbon-balance model of forest growth designed to simulate biomass production of pure, even-aged stands. It is hybrid in the sense that combines physiological processes and empirical relationships. 3-PG comprises four submodels (Landsberg \& Sands, 2011): growth modifiers and NPP, stocking and mortality, biomass allocation and soil water balance. The inputs of the model includes weather data (radiation, temperature, vapour pressure deficit and rainfall), site factors like a fertility rating and initial conditions such as initial biomass, stocking or available soil water. The main outputs are biomass pools and available soil water, forest manager variables like volume or basal area, and physiological responses like NPP, LAI or evapotranspiration. More details about the model structure and outputs can be found in Landsberg \& Waring (1997) and Landsberg \& Sands (2011).

\subsection{Model calibration and climate scenarios}

We first calibrated the model to a stand located in Fuencaliente (Ciudad Real, $38^{\circ} 28^{\prime} \mathrm{N} 4^{\circ} 21^{\prime} \mathrm{W}$ ), by the edge of Sierra Morena in south Spain. The soil type is Xerochrept according to FAO classification and parent material is acidic and mineralogy is mainly quartzite. Soil analysis showed that the fertility is medium-high, the texture classification is sandy-loam. Climate is genuine Mediterranean (Csa according to Köppen's system). In this stand a thinning experiment was set in 1984. Three replicates of three treatments were established within a random complete block experimental design. The treatments were a moderate low thinning (MT), a heavy low thinning (HT) and a control with no thinning (CT). For the calibration the time span of the experiment ranges from 1984 to 2010. Table 4 shows a brief description of state variables at the beginning and at the end of the experiment.

Table 4. Summary of forest variables in Fuencaliente experimental site during the time span of the experiment (from 1984 to 2010).

\begin{tabular}{cccccccc}
\hline Treatment & Age & $\begin{array}{c}\mathrm{N} \\
\left.(\mathrm{stems} \mathrm{ha})^{-1}\right)\end{array}$ & $\begin{array}{c}\mathrm{Dg} \\
(\mathrm{cm})\end{array}$ & $\begin{array}{c}\mathrm{BA} \\
\left(\mathrm{m}^{2} \mathrm{ha}^{-1}\right)\end{array}$ & $\begin{array}{c}\mathrm{V} \\
\left(\mathrm{m}^{3} \mathrm{ha}^{-1}\right)\end{array}$ & $\begin{array}{c}\text { Ho } \\
(\mathrm{m})\end{array}$ & $\begin{array}{c}\text { Wa } \\
\left(\mathrm{Mg} \mathrm{dm} \mathrm{ha}^{-1}\right)\end{array}$ \\
\hline
\end{tabular}




\begin{tabular}{cccccccc} 
CT & 33 & 1193 & 22.9 & 49.0 & 311.4 & 14.9 & 142.1 \\
& 59 & 870 & 31.3 & 67.0 & 589.9 & 20.6 & 249.2 \\
\hline MT & 33 & 1420 & 21.2 & 49.6 & 320.8 & 15.3 & 144.7 \\
& 59 & 427 & 37.4 & 46.6 & 433.2 & 21 & 185.9 \\
\hline HT & 33 & 1570 & 20.4 & 51.4 & 322.8 & 14.9 & 145.5 \\
& 59 & 340 & 39.3 & 41.3 & 385.2 & 20.6 & 165.2
\end{tabular}

CT is unthinned plots, MT are moderate thinned plots, HT is heavy thinned plots, $N$ is stocking, $D g$ is quadratic mean diameter, BA is basal area, $V$ is mean volume, Ho is dominant height and Wa is above ground woody biomass, including branches.

Model parameters were calibrated using data from different sources: a litterfall experiment in the same plots (Roig et al., 2005); biomass data from the site and from young afforestations in Central Spain to obtain biomass allocation parameters; sample needles to fit age-dependent SLA functions; and monthly climatic data for the studied period (reference climate) extracted from a close weather station of the Spanish Meteorological Agency (AEMET). Parameters with lacking information were set to default value according to Sands (2004). Details of the calibration can be requested to authors (Bravo-Oviedo et al., 2011). Figure 3 shows the performance of the calibration with observed mean annual climate in monthly time step.

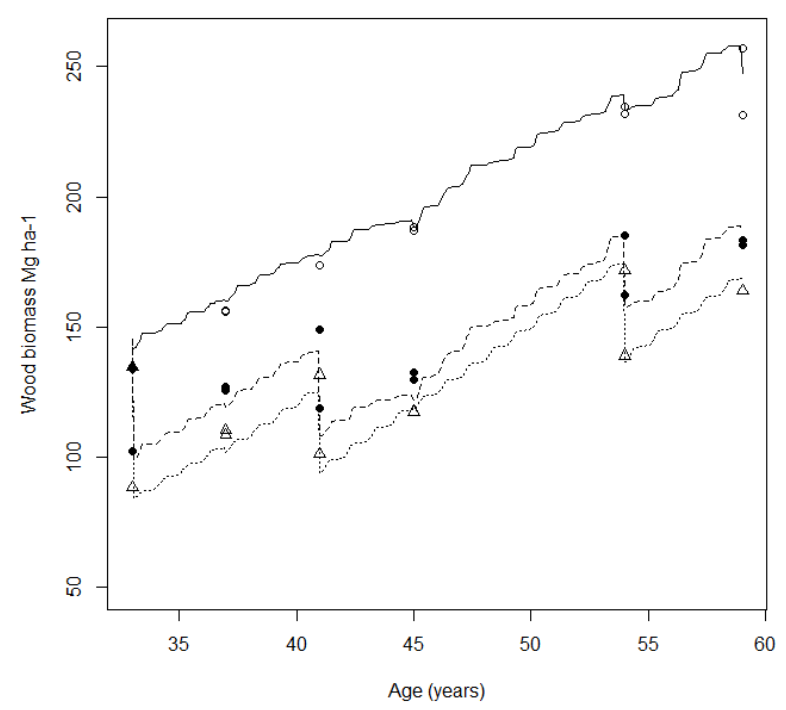

Figure 3. Woody biomass (Mg dry matter $\mathrm{ha}^{-1}$ ) trajectory of observed data and 3-PG output after calibration of an afforested $P$. pinaster Ait. ssp mesogeensis stand. Open circles are observed data 
in control plots; solid circles are observed data in MT plots; triangles are observed data in HT plots. Lines are 3-PG monthly estimates. Solid line CT plots; dashed line MT plots; dotted line HT plots.

In order to evaluate the role of this thinning regime in mitigating climate change effects we developed a climate change scenario based on RCP8.2 scenario (van Vuuren et al., 2011). According to the fifth Assessment Report projections in the Iberian Peninsula (MAGRAMA, 2013) by 2035 winter temperature would increase $0.9{ }^{\circ} \mathrm{C}$, summer temperature would increase $1.4{ }^{\circ} \mathrm{C}$ with a mean annual temperature increase of $1.1{ }^{\circ} \mathrm{C}$. Precipitation would drop $1 \%$ in winter, $3 \%$ in summer and $2 \%$ annually. In addition we arbitrarily reduce the available soil water in $5 \%$ for this scenario.

\subsection{Simulation results}

The simulated woody biomass under reference and changing climate is presented in table 5. Standing C stock decreases with thinning intensity in both climate scenarios, although the impact of thinning is 5.2\% and 3.3\% lower in the simulated scenario for HT and MT regimes respectively. The climate effect on unthinned stands is therefore higher than in thinned stands. When $\mathrm{C}$ losses due to mortality and harvest are incorporated in the $\mathrm{C}$ computation the total woody $\mathrm{C}$ production is higher in thinned stands. Under changing climate the impact of thinning is also higher in heavier thinned stands (HT), but with little climate impact on total woody $\mathrm{C}$ between scenarios.

A trade-off between standing and total woody $\mathrm{C}$ production is consistent with previous reports about the role of thinning in mitigating (D’Amato et al. 2011). In the climate scenario tested heavy thinning can play an important role in mitigating negative climate effects. Although standing $\mathrm{C}$ stock is reduced in both scenarios, under harsher conditions the $\mathrm{C}$ loss is lower in HT plots. Interestingly total $\mathrm{C}$ production (including off-site carbon) is virtual the same in heavy thinned stands in both scenarios. Our results suggest that strongest reduction in competition might benefit remaining trees in drier conditions.

Table 5. 3-PG simulation results of standing and total woody $C\left(\mathrm{Mg} \mathrm{C} \mathrm{ha}^{-1}\right)$ in Fuencaliente in two climate scenarios and three treaments

\begin{tabular}{cccccccc}
\hline Scenario & Treatment & $\begin{array}{c}\text { Standing } \\
\text { woody C }\end{array}$ & $\begin{array}{c}\text { Within } \\
\text { scenario } \\
\text { thinning } \\
\text { impact }\end{array}$ & $\begin{array}{c}\text { Between } \\
\text { scenario } \\
\text { climate } \\
\text { impact }\end{array}$ & $\begin{array}{c}\text { Total } \\
\text { woody C } \\
\text { production }\end{array}$ & $\begin{array}{c}\text { Within } \\
\text { scenario } \\
\text { thinning } \\
\text { impact }\end{array}$ & $\begin{array}{c}\text { Between } \\
\text { scenario } \\
\text { climate } \\
\text { impact }\end{array}$ \\
\hline $\begin{array}{c}\text { Reference } \\
\text { climate }\end{array}$ & CT & 126.3 & - & - & 136.4 & - & - \\
& MT & 95.3 & -24.5 & - & 152.1 & 11.6 & - \\
\hline
\end{tabular}




\begin{tabular}{cccccccc} 
& HT & 86.2 & -31.7 & - & 153.7 & 12.7 & - \\
\hline $\begin{array}{c}\text { RCP8.5- } \\
\text { based }\end{array}$ & CT & 115.1 & - & -8.9 & 127.4 & - & -6.6 \\
& MT & 90.7 & -21.2 & -4.8 & 142.6 & 12.0 & -6.2 \\
& HT & 84.6 & -26.5 & -1.9 & 151.4 & 18.9 & -1.5
\end{tabular}

Reference climate is mean actual climate (1984-2010). Within scenario thinning impact compares MT and HT in relation to CT output. Between scenario climate impact compares the same thinning regime output in RCP8.5-based scenario vs. reference climate.

Thinning is a key treatment to reduce the impact of extreme droughts on tree growth in Mediterranean pines (Martín-Benito et al., 2010b; Fernández de Uña et al., 2015). As our results highlight, under a drier climate scenario the loss of on-site carbon due to heavy thinning may be lower while the total $\mathrm{C}$ higher than in un-thinned stands. Therefore, the application of thinning in Mediterranean pinewoods is a crucial strategy for forest adaptation and climate change mitigation.

\section{Carbon sequestration in even and uneven aged stone pine stands}

Stone pine (Pinus pinea L.) stands have traditionally been managed as even-aged with low stocking densities, facilitating crown growth and increased light resulting in greater cone production. However, uneven-aged stands also exist as a consequence of factors such as advanced recruitment, failure of natural regeneration, the impacts of animal grazing, and the preservation of older, large, cone-producing trees. Today, some of these stands are maintained and managed as uneven-aged to protect soils (especially, dune ecosystems), in landscaping, as recreational areas, or for fruit production. There are some local records on the management of these stands (Finat et al., 2000, Montero et al., 2003) as well as some studies comparing growth and cone yield in even and unevenaged stone pine stands (Río et al., 2003; Calama \& Montero, 2007; Calama et al. 2008a). However, no studies on the inclusion of carbon sequestration were found. In this section we analyse the influence of age structure on carbon sequestration in stone pine stands by comparing carbon stocks following even-aged and uneven-aged management. For this purpose, an individual-tree growth model and biomass equations were used.

\subsection{Growth and yield model}

The PINEA2 model is an integrated single-tree model, oriented towards multiple use management of stone pine stands. This model allows the growth and yield of a stand to be simulated under different management schedules and thinning regimes. The 
simulations are carried out in five-year steps, defining the state of every tree within the stand at each stage of simulation. The model consists of three different modules: site quality, transition and state. The state module includes, among others, a taper function which allows end-use classification of timber volume according to size; a discriminant function for predicting probability of stem rot by Phellinus pini, and an equation for estimating annual cone production. The PINEA2 model was initially constructed and validated for even-aged stands. Further details regarding the PINEA2 model for evenaged stands can be found in Calama et al. (2007) and Calama et al. (2008b). Given the single-tree character and the stochastic formulation of the functions included in the model, it was possible to calibrate it for a multi-aged complex forest structure, resulting in PINEA_IRR model (see Calama et al. 2008a). This calibrated version also presents a modular structure, including specific functions for site productivity, state attributes (height-diameter, crown dimensions, taper function and cone production) and diameter increment.

\subsection{Biomass equations and carbon estimations}

Tree biomass (by component) was estimated from diameter at breast height (dbh, measured at $1.3 \mathrm{~m}$ above ground) and total tree height using the biomass equations proposed by Ruiz-Peinado et al. (2011) for stone pine. Carbon in each component is calculated from oven-dry biomass by multiplying each value by 0.508 according to Ibáñez et al. (2002). Those carbon stocks associated with dead wood, litter, and soil organic matter, were not modelled for this assessment.

\subsection{Even and uneven-aged alternatives}

The growth and development of a 1 hectare stand of stone pine located in the Northern Plateau of Spain was simulated under both even-aged and uneven-aged management structures over a 100-year period. In both cases, a site index of $15 \mathrm{~m}$ at a total age of 100 years was assumed. Typical silvicultural programs applied in this region for multiple use management of stands with even and uneven-aged structures were compared:

1. In the even-aged stand, it was assumed that trees belong to the same age class, that the initial density is 500 stems/ha at age 20, and that three thinnings are applied during the cycle: one systematic at age 30 , reducing stand density to 350 stems/ha; and two selective low thinnings at ages 45 and 60, reducing the density to 250 and $150 \mathrm{stems} / \mathrm{ha}$ respectively. Rotation length is assumed to extend up to 100 years, and although shelterwood regeneration fellings are commonly applied during a 20 years period, we simulate single clearcutting at 100 years old.

2. In the uneven-aged structure, it was assumed that the stand displays the uneven equilibrium state (Table 6) proposed by Calama et al. (2005). Selective cuttings were applied every 25 years, removing non-vigorous and non fruit-producing trees in order to maintain a balanced representation of vigorous trees within the different 
age classes, while overmature large cone producer trees are favoured. Sustainability of the management is warranted if basal area ranges between $8-20 \mathrm{~m}^{2} / \mathrm{ha}$, standing stocking volume between $45-100 \mathrm{~m}^{3} / \mathrm{ha}$ and a constant recruitment of 150 saplings $(\mathrm{dbh}>5 \mathrm{~cm})$ per hectare and 25 years period is assumed.

Table 6. Proposed structure for uneven-aged stands of stone pine, rotation period 25 years

\begin{tabular}{cccc}
\hline Age-class & $\begin{array}{c}\text { Before selective } \\
\text { felling }\left(\mathrm{N}^{\circ} \text { trees/ha) }\right.\end{array}$ & $\begin{array}{c}\text { Removed in selective } \\
\text { felling }\left(\mathrm{N}^{\circ} \text { trees/ha) }\right.\end{array}$ & $\begin{array}{c}\text { After selective } \\
\text { felling }\left(\mathrm{N}^{\circ} \text { trees/ha) }\right.\end{array}$ \\
$0-25$ & 110 & 60 & 50 \\
\hline $25-50$ & 90 & 55 & 35 \\
$50-75$ & 35 & 15 & 20 \\
$75-100$ & 20 & 10 & 10 \\
$100-125$ & 10 & 5 & 5 \\
$125-150$ & 5 & 5 & 0 \\
\hline TOTAL & 270 & 150 & 120 \\
\hline
\end{tabular}

\subsection{Carbon sequestration in even and uneven-aged stands}

The carbon fixed in stands of both age structures over the course of one rotation period (100 years) is presented in Figure 4. The carbon fixed in the even-aged stand

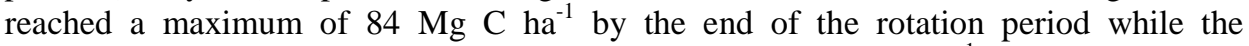
simulated uneven-aged stand resulted in a maximum of $63 \mathrm{Mg} \mathrm{C}^{-1}$ and a minimum of $30 \mathrm{Mg} \mathrm{C} \mathrm{ha}{ }^{-1}$. Taking into account the total cumulative amount of carbon fixed during the 100 year cycle, while even-aged stands accumulate $145 \mathrm{Mg} \mathrm{C} \mathrm{ha}^{-1}$, uneven-aged stands fixed $130 \mathrm{Mg} \mathrm{C} \mathrm{ha}^{-1}$, thus being more effective in this role. It also should be pointed out that the uneven-aged stand maintained a constant stock of fixed carbon over $27 \mathrm{Mg} \mathrm{C} \mathrm{ha}{ }^{-1}$ which was never extracted from the forest. 


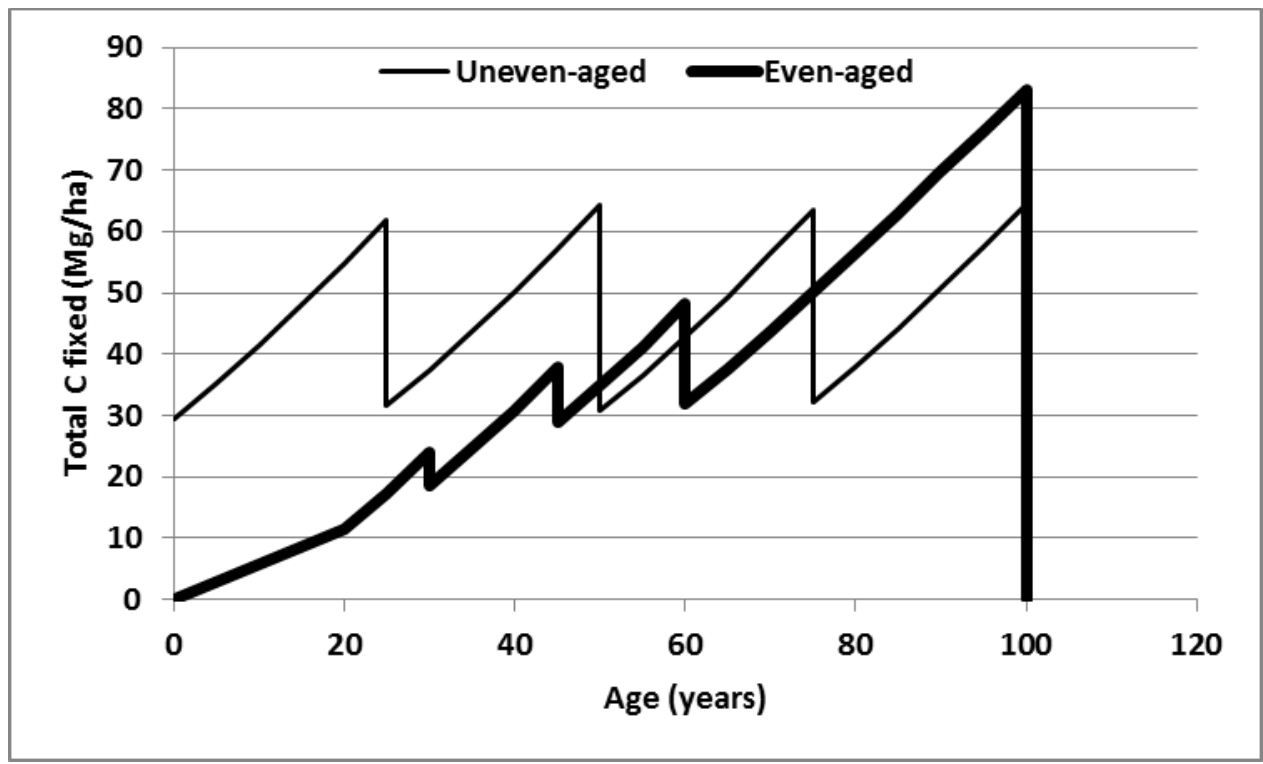

Figure 4. Total above and belowground carbon fixed by even and uneven-aged stands of stone pine over a period of 100 years.

If we take into consideration the annual growth of above and belowground biomass as well as annual cone production, the uneven-aged stand fixed $0.14 \mathrm{Mg} \mathrm{C} \mathrm{ha}^{-1} \mathrm{yr}^{-1}$ more carbon than the even-aged stand (Table 7), which means a difference of $13.6 \mathrm{Mg} \mathrm{C}$ $\mathrm{ha}^{-1}$ over the 100 year period.

Table 7. Annual increments of above and belowground biomass, annual cone production (dry weight) and their equivalents in $C$ fixed in even and uneven-aged stands of stone pine

\begin{tabular}{cccccc}
\hline & & Aboveground & Belowground & Cones & Total \\
\hline Biomass & even-aged & 1721.1 & 525.3 & 76.1 & 2322.5 \\
$\left(\mathrm{~kg} \mathrm{ha}^{-1} \mathrm{yr}^{-1}\right)$ & uneven-aged & 2034.4 & 520.9 & 108.2 & 2663.5 \\
\hline $\mathrm{C} \mathrm{fixation}$ & even-aged & 0.873 & 0.267 & 0.055 & 1.195 \\
$\left(\mathrm{Mg} \mathrm{C} \mathrm{ha}^{-1} \mathrm{yr}^{-1}\right)$ & uneven-aged & 1.031 & 0.265 & 0.038 & 1.334 \\
\hline
\end{tabular}

Biomass extractions (only aboveground biomass) totalled 87.3 $\mathrm{Mg} \mathrm{C} \mathrm{ha}^{-1}$ of fixed carbon in the case of an even-aged structure, which was removed in three thinning interventions and at the final harvest at an age of 100 years (Figure 5). Around $60 \mathrm{Mg} \mathrm{C}$ $\mathrm{ha}^{-1}$ of this carbon was fixed in stems and large branches, which are used as pulpwood and saw timber, while the rest belongs to tree components which remain in forest and 
decompose. In uneven-aged stands, four thinning treatments were applied over the 100 years (every 25 years), removing $103 \mathrm{Mg} \mathrm{C} \mathrm{ha}^{-1}$ of fixed carbon, of which $75 \mathrm{Mg} \mathrm{C} \mathrm{ha}^{-1}$, destined for the timber industry (Figure 5).

In terms of productivity, the uneven-aged structure favours cone production, which is one of the main objectives in the management of stone pine forests. In terms of weight of green cones (dry weights in table 7), which is the commonly used trade unit, throughout the 100 year cycle uneven-aged stands produce $171 \mathrm{~kg} \mathrm{ha}^{-1} \mathrm{yr}^{-1}$, while even aged stands only produce $120.8 \mathrm{~kg} \mathrm{ha}^{-1} \mathrm{yr}^{-1}$. However, contribution of cone production to $\mathrm{CO}_{2}$ fixation can be considered negligible, since most of the cones are collected each year to obtain edible pine nuts, while the residuals of the industrial process of pine nut extraction are usually burned. With respect to timber production, the uneven-aged structure is also more favourable, although in that case, as bigger trees are harvested at rotation ages over 125 years, main part of this timber is affected by stem rot due to Phellinus pini, thus much of the timber production ends up as pulpwood or firewood, with less than $10 \%$ of total stem volume transferred to sawmill industry. Both pulpwood and firewood uses result in short term return of carbon to the atmosphere. On the contrary, while even-aged structure lead to less amount of total biomass fixed, approximately $50 \%$ of the harvested timber volume can be used for sawmills, resulting in extended periods of carbon return to the atmosphere.

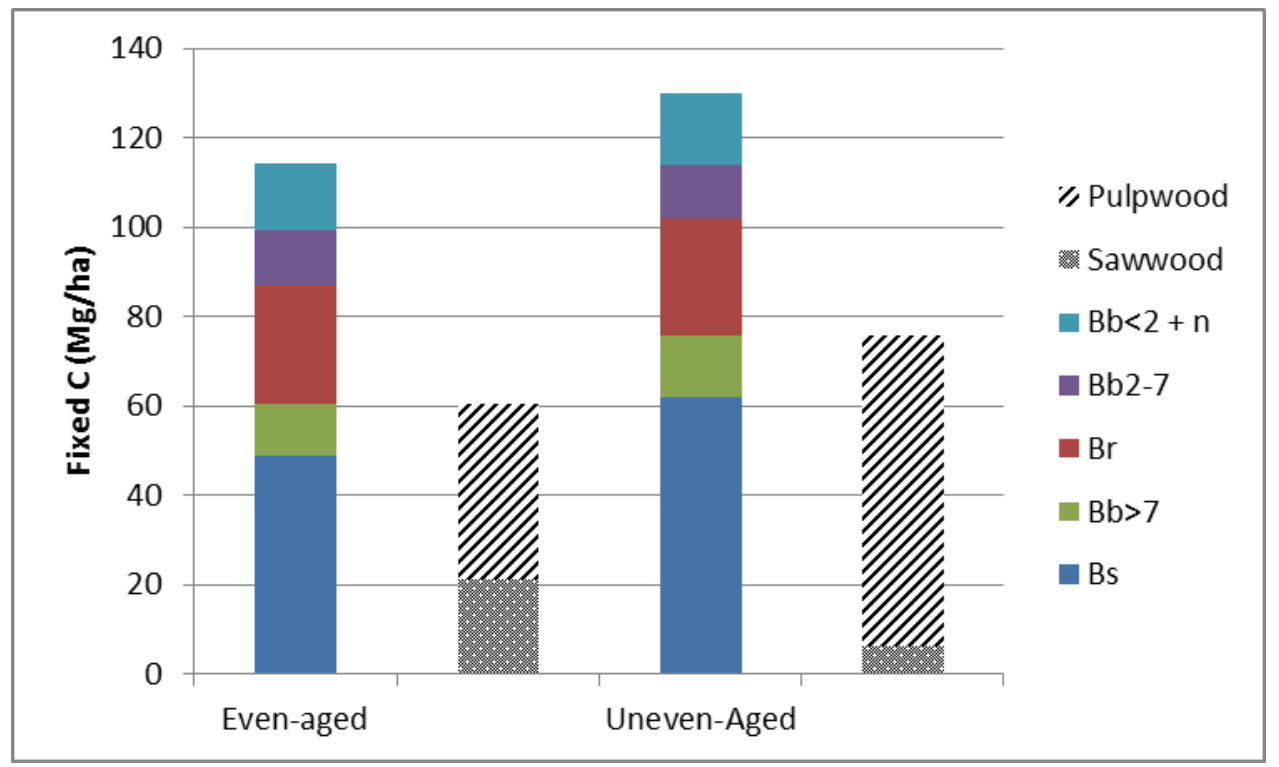

Figure 5. Carbon fixed in extracted biomass by component over the 100-year period in even and uneven-aged stands of stone pine. $\mathrm{Bs}, \mathrm{Bb}<_{2+n}, \mathrm{Bb} b_{2-7}, \mathrm{Bb}>_{7}$, and $\mathrm{Br}$ correspond to: stem, branches under $2 \mathrm{~cm}$ diameter plus needles, branches between 2 and $7 \mathrm{~cm}$ diameter, branches larger than 7 
$\mathrm{cm}$ diameter and roots. Saw wood includes stem timber free from rot affection obtained from sections with diameter $>30 \mathrm{~cm}$; fuel wood includes the rest of the stem timber as well as branches larger than $7 \mathrm{~cm}$

To define the best age structure for a stand is a complex decision. Many forest products and services depend on age structure like wood and non-wood production, $\mathrm{CO}_{2}$ fixation, soil protection, habitat function, etc. and some of them are difficult to quantify and to compare between different age structures. The carbon estimation for even and uneven aged stands using growth models and biomass equations is a good option to include carbon sequestration in the decision making on selecting age structure.

\section{Modelling coarse woody debris in pine plantations}

Dead wood is a key component in the ecological processes of forest ecosystems. Although it is recognised that decaying logs and snags play an important role in forest biodiversity (Harmon et al., 1986; Esseen et al., 1992; McComm \& Lindenmayer, 1999), little is known about dead wood dynamics in Mediterranean forests, where factors such as biodiversity conservation and carbon sequestration are of great importance.

The dynamics of this ecosystem is comprised of periods of undisturbed natural growth interrupted by natural disturbances produced by fire, wind etc, or human intervention such as thinning or pruning. These disturbances, either small-scale gap perturbations or stand replacing catastrophic events, continuously replenish and create coarse woody debris (CWD) (Hansen et al., 1991). Under the paradigm of sustainable yield forest management, dead trees have been minimised to avoid pest problems and other hazards. However, in recent decades, forestry has been addressed towards a more close-to-nature approach with the aim of developing forest stands that are comparable to natural ones in so far as structure, composition and regeneration processes (Bauhus et al., 2009). In this perspective, silvicultural restrictions on CWD removal have been proposed or introduced in many regions (Keeton \& Franklin, 2005). These prescriptions lead to create an adequate stock of CWD and promote CWD structures for maintaining biodiversity (Siitonen et al., 2000). In contrast, nowadays, the growing interest in harvesting logging residues for energy production might reduce both the size and the diversity of woody debris (Wright, 2006).

Trees which die as a result of insect damage, disease or fire are commonly harvested immediately where economy and accessibility permit (DeBell et al., 1997). Today, the increasing importance given to both biodiversity and the carbon stocks in forests has led to the preservation and promotion of dead wood in managed forests. Forest and wildlife managers have suggested that 5 to 10 snags per hectare are adequate to maintain the biodiversity (Hunter, 1990). Nevertheless, CWD and its relative contribution to the total ecosystem biomass vary greatly, depending on forest types, disturbance regimes, topography and stand characteristics (Spies et al., 1988; Harmon \& Hua, 1991). 
In practice, snag and log dynamics are important to define the appropriate quantity, density, size (both diameter and height), distribution and state of decay of CWD in different site conditions and forest types (Hart, 1999, Woldendrop et al., 2004; Christensen et al, 2005; Stephens \& Moghaddas, 2005). Studies which focus on modelling the abundance of snags and logs in Mediterranean type forest ecosystems are scarce (Montes \& Cañellas, 2006). In this section, a snag/log abundance model is presented along with a carbon content equation for Mediterranean pine plantations composed of Pinus sylvestris L., P. pinaster Ait. and P. nigra Arn. in northern Spain.

\subsection{Database}

The study area, situated in the north of Spain, constitutes a homogeneous transitional zone with altitudes ranging from 800 to 1000 m.a.s.l., and an area of about 186,617 ha. The climate is Mediterranean with a slight Atlantic influence. Forests cover 59,471 ha (31.9 \% of total area) and are characterised by extensive stands of Quercus pyrenaica Wild., Q. ilex L. and Q. faginea Lam.. As a result of an extensive pine plantation program carried out during the 60's, Pinus spp. stands cover $49.4 \%$ of the total forested surface of this area. The three main species composing the Pine plantations are Pinus sylvestris (23\%), P. nigra (21\%) and P. pinaster (5\%). The soil in this region is mainly acidic, although there are also some limestone and neutral soils (Oria de Rueda et al., 1996).

Sixty six plots were installed in the study area in Pinus spp. planted stands (34 with a predominance of Pinus sylvestris, 24 of $P$. nigra and 8 of $P$. pinaster). The plots were composed of four subplots joined by two perpendicular transects of $50 \mathrm{~m}$. One of these subplots was a National Forest Inventory (NFI) plot with four concentric radii (Bravo and Montero, 2003) and the three other subplots were situated at the three vacant extremes of the two transects. An inventory of snags was performed in the four subplots while an inventory of logs was taken in the transects. The snags inventory was carried out by sampling 20 trees, spiralling out from the centre. Starting with the trees that were closest to the centre of the plot and moving progressively away, the condition of the trees was recorded, i.e. whether they were alive or dead. For large dead trees (diameter outside bark at breast height (diameter at breast height, $d b h \geq 7.5 \mathrm{~cm}$ ), the variables recorded were: species, snag height, dbh, state of decomposition, presence of excavated cavities, and azimuth and distance to the centre of the plot. The log inventory was carried out in the two perpendicular transects which joined the four subplots. Fallen dead trees with a diameter greater than $7.5 \mathrm{~cm}$ and a length greater than $1 \mathrm{~m}$ were considered logs. The following variables were measured: species, diameter at the interception point, length, state of decomposition and wildlife characteristics. Decomposition classes were considered following the criterion by Sollins (1992).

The snag basal area $\left(\mathrm{m}^{2}\right)$ and $\log$ volume $\left(\mathrm{m}^{3}\right)$ were calculated for each plot. The individual basal area for each tree was totalled for each plot and the values scaled up to give a basal area per hectare. The log volume was estimated through the equation $\mathrm{V}_{\mathrm{i}}=(\pi$ $\left.{ }^{2} \mathrm{~d}_{\mathrm{i}}^{2}\right) /$ LL (Warren \& Olsen, 1964; Van Wagner, 1968), where V: log volume ( $\left.\mathrm{m}^{3} / \mathrm{ha}\right)$, d: diameter of each $\log (\mathrm{cm}), \mathrm{L}$ : total length of the transects, which in this case was $100 \mathrm{~m}$. 
An intensive inventory of logs with a diameter greater than $1 \mathrm{~cm}$ and lower than $7.5 \mathrm{~cm}$ was carried out in 32 out of the sixty six study plots. This inventory was performed in the $10 \mathrm{~m}$ closest to the intersection of the two transects. The variables recorded for each log were: species, diameter at the interception point, length, weight, state of decomposition and wildlife characteristics. The mean diameter, mean length and mean weight were calculated by each plot. The total carbon content in samples of woody debris from each plot was measured through the instantaneous combustion of fragment samples in an oven at $550^{\circ} \mathrm{C}$.

A description of the main stand variables is presented in Table 8. The following characteristics were also recorded for each plot: number of non-inventoried stems, site conditions (soil texture, soil organic matter, $\mathrm{pH}$, soil type, altitude, stoniness, slope, exposure and radiation), climate characteristics (rainfall, maximum, mean and minimum temperature, dry month rainfall obtained through a digital climatic atlas (Ninyerola et al., 2005)) and forest management history (harvests and thinning over the previous 15 years).

Table 8. Database characteristics used to develop the snag and log models for a pine plantation in Northern Spain. $N$, trees per ha; $B A$, basal area; $D$ g, quadratric mean diameter; $B A_{\text {snags }}$, basal

\begin{tabular}{ccccc}
\multicolumn{5}{c}{ area of snags; $V_{\text {logs }}$, volume of logs } \\
\hline Variable & Mean & Minimum & Maximum & $\begin{array}{c}\text { Standard } \\
\text { deviation }\end{array}$ \\
\hline $\mathrm{N}\left(\right.$ trees ha $\left.^{-1}\right)$ & 803 & 26 & 1585 & 341 \\
$\mathrm{BA}\left(\mathrm{m}^{2} \mathrm{ha}^{-1}\right)$ & 23.2 & 5.6 & 39.3 & 8.2 \\
$\left.\mathrm{Dg}(\mathrm{cm})^{-1}\right)$ & 22.2 & 13.2 & 58.3 & 6.3 \\
$\mathrm{BA}_{\text {snags }}\left(\mathrm{m}^{2} \mathrm{ha}^{-1}\right)$ & 0.2 & 0.0 & 1.2 & 0.3 \\
$\mathrm{~V}_{\text {logs }}\left(\mathrm{m}^{3} \mathrm{ha}^{-1}\right)$ & 1.5 & 0.0 & 5.9 & 1.9 \\
\hline
\end{tabular}

\subsection{Modelling approach}

\subsubsection{Two step regression approach}

A two step regression approach (Woollons, 1998; Alvarez-González et al., 2004; Bravo et al., 2008) was used to model the presence of CWD in pine plantations. In the first step, a logistic model was fitted to predict the probability of CWD presence, and in the second step, linear models were used to predict the basal area of snags and the volume of logs.

In the logistic model (Eq. 1), $\mathrm{P}$ is the probability of the presence of CWD, which is bound between 1 (presence) and 0 (absence), $\alpha$ is the intercept term, $\Sigma b_{i} X_{i}$, is the linear combination of parameters $b_{i}$ and independent variables $X_{i}$, and $e$ is the natural logarithm base.

$$
P=\left(1+e^{-\left(\alpha+\sum b_{i} X_{i}\right)}\right)^{-1}
$$


Several predictor variables were tested among stand variables, site variables, climate variables and forest management history. Final logistic regression equations included only significant predictors $(\mathrm{p} \leq 0.05)$. The goodness of fit was evaluated using the Hosmer \& Lemeshow test (1989) and the Akaike Information Criterion (Zhang et al., 1997). PROC LOGISTIC SAS 8.1 statistical program was used in the process (SAS, 2001). Receiver Operating Characteristic (ROC) curves for each model were used to compare the accuracy of different logistic regression models.

Lineal models were used, as a second step, to predict the abundance of snags and logs (in terms of basal area and volume respectively) in plots where the presence of CWD were predicted by using logistic model and a threshold value of 0.60 . The linear model was:

$$
\hat{y}=a_{0}+\sum a_{j} X_{j}
$$

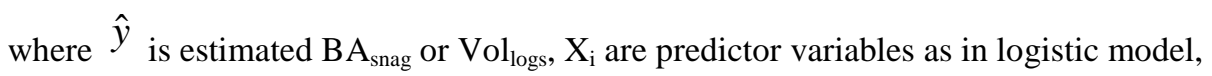
and $a_{0}$ and $a_{j}$ are parameters to be estimated.

The precision of the two-step models were analyzed by comparing residual variance and dependent sample variance (eq. 3) and by fitting a straight line between actual and predicted values (Huang et al., 2003) where slope and independent term should be equal to 1 and 0 respectively.

$$
R^{2}=100 *\left(1-\frac{S_{e}^{2}}{S_{y}^{2}}\right)
$$

where $\boldsymbol{S}_{\boldsymbol{e}}^{2}$ and $S_{y}^{2}$ are, respectively, the residual sample's variance and the dependent variable sample's variance.

\subsubsection{Carbon Content model}

A linear model was also used to estimate the carbon content of logs in the stands, where their presence was predicted using the logistic model. In this model, $y$ is $\mathrm{C}_{\operatorname{logs}}$ (carbon content in logs in \%), and possible predictor variables $\left(X_{i}\right)$ were: species ( $1=$ Pine and $0=$ Otherwise) and decomposition classes as dummy variables, mean diameter, mean length and mean weight of logs, stand variables, physiographic variables, and climatic variables. Interactions between species and stand variables were also checked as predictive variables.

The goodness of fit for the carbon model was assessed using the coefficient of determination. Graphical and numeric analyses of the residuals $\left(e_{i}\right)$ were performed to check assumptions of linearity, normality, and homogeneity of variance. Predictor variables were retained in the models if $\mathrm{p}<0.05$. 


\subsection{CWD models}

\subsubsection{Snags and logs models}

The final logistic model to predict the presence of CWD (eq 5) includes as independent variables altitude, minimum temperature, clay and silt content and a dummy variable indicating if harvest operation has been carried out in the last 5 years. The Akaike information criterion was 79.709, and the Hosmer \& Lemeshow test (Pr $>0.5817$ ) revealed no lack of fit. To determine the presence of CWD, a 0.60 threshold value was used, resulting in $68.2 \%$ of Pinus plots with CWD classified correctly (sensitivity equal to $51.5 \%$ and specificity equal to $84.8 \%$ ). The area under the ROC curve was 0.7087 .

$$
P=\left(1+e^{-(-43.2715+2.5501 \text { Alt }+0.3939 \text { MinT+4.6453ClayText }+2.4439 \text { SiltText }+2.5136 \text { Harvesting }}\right)^{-1}
$$

where Alt is altitude, m; MinT is minimum temperature, ${ }^{\circ} \mathrm{C}$; ClayText and SiltText are dummy variables for clay and silt textured soils, respectively, both equal to 0 for sandy soils, and Harvesting is a dummy variable with 1 for harvest and 0 for no harvest.

The final linear models for snag basal area and log volume resulted in adjusted coefficients of determination of $17.47 \%$ for snags (Eq. 6) and $46.05 \%$ for logs (Eq. 7). The figure for snags increases with a decrease in the precipitation in June, whereas the volume of logs increases with an increase in the basal area of the stand and when the dominant height decreases.

$$
\begin{gathered}
\hat{B} A_{\text {snags }}=2.1846-0.0038 \cdot P_{-} \text {june } \\
V \hat{l_{\log s}}=0.8821+0.2046 \cdot B A-0.4028 \cdot \mathrm{Ho}
\end{gathered}
$$

where $\hat{B} A_{\text {snags }}$ is the predicted basal area of snags in $\mathrm{m}^{2} /$ ha and $V \hat{o} l_{\log s}$ is the predicted volume of logs in $\mathrm{m}^{3} / \mathrm{ha}$. BA_msp is the basal area of the main species in $\mathrm{m}^{2} / \mathrm{ha}$, BA is the basal area of the stand in $\mathrm{m}^{2} / \mathrm{ha}$, and Ho is the dominant height in $\mathrm{m}$.

The proposed two-step model achieves joint model accuracy equal to $39.25 \%$ and $62.75 \%$ for snags and logs respectively. Graph analysis of real and predicted values indicated that the joint model showed no lack of fit. The results of this empirical study may serve to understand more clearly the processes associated with an abundance of snags and logs.

\subsubsection{Carbon content model}

The final carbon content model obtained for logs (Eq. 8) resulted in a coefficient of determination of $53.33 \%$ (adjusted coefficient of determination was $47.50 \%$ ). The carbon content of logs increases with an increase in the diameter of the logs, secondly, when the basal area of the stand increases, and finally, in the presence of small Pinus sp trees. The latter situation suggests early stages of development in a stand where no management intervention has been carried out as yet. Therefore, in this area, forest 
management plays an important role in the total coarse woody debris carbon sequestration.

$$
\hat{C}_{\log s}=-54.5741+0.6594 m \log \text { diam }+0.0346 B A-0.0003 S p * n
$$

where mlogdiam is the mean diameter of the logs $(\mathrm{cm})$; BA is the basal area of all live trees in the stand $\left(\mathrm{m}^{2} / \mathrm{ha}\right)$, and $\mathrm{Sp}^{*} \mathrm{n}$ is an interaction between species dummy variables and the number of small stems (trees with diameter $<7.5 \mathrm{~cm})$ (trees/ha). Forest management decisions are based on information regarding current and future forest conditions, so it is often necessary to project the changes in the system over time. The equations obtained allow us to predict the presence of CWD and quantify the amount of snags and logs in pine plantations in northern Spain.

The significant role of dead wood in carbon pooling linked to biodiversity is becoming clearer. The studied Pinus spp. planted stands show values of $0.78 \mathrm{Mg} \mathrm{C}$ ha-1, which represents the $1 \%$ of the total Carbon fixed in the ecosystems. This percentage is small because of the huge importance of tree live biomass and responds to stand histories and forest legacy, where forest management has been oriented to maximize the commercial value of the harvest and avoid different risks. However, CWD proportion can be a criterion for assessing and determining baseline silvicultural practices at biodiversity level. In this sense, these results can be useful for guidelines for prescribing adequate levels of CWD in terms of density, size and amount in the different components of dead wood.

The two-step model emphasised the importance of forest management in CWD presence in this region and allowed us to combine knowledge (understanding and data) and prediction of system dynamics. Unmanaged forests in Spain are scarce because of centuries of forestry practices. Intensive management activities have led to timber removal and woody material loss for centuries. However, Mediterranean forests currently present a low silviculture activity because of the harvest economic yield. In this sense, the two-step model can provide objective forecasts and information for exploring management options and silvicultural alternatives for sustainable forest management.

\section{Conclusions}

Our results showed how carbon sequestration changes over time, and with different management regimes in Mediterranean pine forests. The rotation length, thinning intensity, stand composition, as well as age structure influenced carbon stocks and carbon sequestration rates, with different results amongst species. A less intense management regime with the extension of rotation length 20 years increased carbon stocks in Scots pine forests. However, for Mediterranean maritime pine heavy thinning increased carbon sequestration when carbon fixed in removed wood was also considered. This highlights the importance of forest management, because despite unmanaged forests can show a higher amount of carbon on-site, managed stands can 
fixed more off-site carbon while being in a better condition in relation to climate change effects (droughts, pets or diseases, fires...).

Forest growth models are valuable tools to predict carbon fixation in forest systems under different management alternatives. The use of hybrid models such as 3-PG offers the possibility of estimating the growth response to climate, giving reliable information about the impact of climate change on forest carbon stocks. On the other hand, more detailed empirical model as PINEA2 and PINEA_IRR allowed us to study the effect of age structure on different carbon components, including cone production and wood products with different life cycles which may be considered in carbon accounts.

Dead wood management (size, amount, density, decomposition status and their distribution throughout the forest) is currently one of the most important questions to be resolved for forest management in the context of sustainability and biodiversity conservation. Accurate prediction and quantification of dead wood in the ecosystems is the first step to understanding the CWD dynamic. The models presented for coarse woody debris allow quantifying the biomass accumulated in this component, and therefore to furthering our understanding of the carbon cycle in pine forests.

7. AcknowledgmentsThis work has been funded through the following research projects: AGL-2010-15521; AGL2011-29701-C02-01; AGL2011-29701-C02-02; AGL2010-21153-C02; AGL2013-46028R; AT2013-004; RTA-2013-00011-C2.

\section{References}

Álvarez González, J.G., Castedo Dorado, F., Ruiz González, A.D., López Sánchez, C.A. \& von Gadow, K. (2004). A two-step mortality model for even-aged stands of Pinus radiata D. Don in Galicia (Northwestern Spain). Annals of Forest Science, 61, 441450.

Andreu, L., Gutiérrez, E., Macias, M., Ribas, M., Bosch, O. \& Camarero, J.J. (2007). Climate increases regional tree-growth variability in Iberian pine forests. Global Change Biology, 13, 1-12.

Balboa-Murias, M.A., Rodríguez-Soalleiro, R., Merino, A., \& Alvarez-González, J.A. (2006). Temporal variations and distribution of carbon stocks in aboveground biomass of radiata pine and maritime pine pure stands under different silvicultural alternatives. Forest Ecology and Management, 237, 29-38.

Bauhus, J., Puettmann, K., Messier, C. (2009). Silviculture For Old-Growth Attributes. Forest Ecology and Management, 258, 525-537.

Bogino, S.M., Bravo Oviedo, F., \& Herrero de Aza, C. (2006). Carbon dioxide accumulation by pure and mixed woodlands of Pinus sylvestris L. and Quercus pyrenaica Willd. in Central Mountain Range (Spain). In: Bravo Oviedo, F. (Ed.). 
Proceedings of the IUFRO Div. 4 International Meeting "Managing Forest Ecosystems: the Challenges of Climate Change”. Ed. Cuatroelementos, Valladolid. 98p.

Bravo, F., Pando, V., Ordóñez, C., \& Lizarralde, I. (2008). Modelling ingrowth in Mediterranean pine forests: a case study from Scots pine (Pinus sylvestris L.) and Mediterranean Maritime pine (Pinus pinaster Ait.) stands in Spain. Investigación Agraria: Sistemas y Recursos Forestales, 17(3), 250-260.

Bravo-Oviedo, A., Tomé, M., Río, M., \& Montero, G. (2011). Calibración del modelo 3PG para repoblaciones de pino negral sometidas a diferente tratamiento de claras. III Forest Model group meeting. Spanish Society of Forest Science. 4-6 May 2011, Lugo, Spain (Oral presentation, unpublished).

Cairns, M.A., Brown, S., Helmer, E.H., \& Baumgardner, G.A. (1997). Root biomass allocation in the world's upland forests. Oecologia, 111, 1-11.

Calama, R., Finat, L., Gordo, F.J, Bachiller, A., Ruíz-Peinado, R., \& Montero, G. (2005). Estudio comparativo de la producción de madera y piña en masas regulares e irregulares de Pinus pinea en la provincia de Valladolid. IV Congreso Forestal Español. Mesa 3. SECF y Diputación General de Aragón. Zaragoza.

Calama, R., \& Montero, G. (2007). Cone and seed production from Stone Pine (Pinus pinea L.) stands in Central Range (Spain). European Journal of Forest Research, 1256(1), 23-35.

Calama, R. Sánchez-González, M., \& Montero G. (2007). Management oriented growth models for multifunctional Mediterranean forests: the case of stone pine (Pinus pinea L.) .EFI Proceedings, 56, 57-70.

Calama, R., Barbeito, I., Pardos, M., del Río, M., \& Montero, G. (2008a). Adapting a model for even-aged Pinus pinea L. stands fo complex multi-aged structures. Forest Ecology and Management, 256, 1390-1399.

Calama, R., Mutke, S., Gordo, J.M., \& Montero, G. (2008b). An empirical ecologicaltype model for predicting stone pine (Pinus pinea L.) cone production in the Northern Plateau (Spain). Forest Ecology and Management, 255 (3/4), 660-673

Campbell, J., Alberti, G., Martin, J., \& Law, B.E. (2009). Carbon dynamics of a ponderosa pine plantation following a thinning treatment in the northern Sierra Nevada. Forest Ecology and Management, 257, 453-463.

Castedo-Dorado, F., Gómez-García, E., Diéguez-Aranda, U., Barrio-Anta, M., \& Crecente-Campo, F. (2012). Aboveground stand-level biomass estimation: a comparison of two methods for major forest species in northwest Spain. Annals of Forest Science, 69, 735-746. 
Christensen, M., Hahn, K., Mountford, E. P., Standova, P., Rozenbergar, S., Diaci , J., Wijdeven, S., Meyer, P., Winter, S., \& Vrska, T. (2005). Dead wood in European beech (Fagus sylvatica) forest reserves. Forest Ecology and Management, 210, 267282.

D’Amato, A. W., Bradford, J. B. Fraver, S. \& B. J. Palik. (2011). Forest management for mitigation and adaptation to climate change: Insights from long-term silviculture experiments. Forest Ecology and Management, 262(5), 803-816.

DeBell, D.S., Curtis, R.C., Harrington, C.A. \& Tappeiner, J.C. (1997). Shaping Stand Development through silvicultural practices. In: Creating Forestry for the 21st century. The science of ecosystem management. Edited by Lathryn, A., Kohm \& Jerry F. Franklin. Island Press. 141-151 pp.

Durbán, M., Harezlak, J., Wand, M.P., Carroll, R.J. (2005) Simple fitting of subjectspecific curves for longitudinal data. Statistics in Medicine 24, 1153-1167.

Eilers, P.H.C., \& Marx, B.D. (1996). Flexible smoothing with B-splines and penalties. Statistical Science, 11,89-121.

Esseen, P.A., Ehnström, B., Ericson, L. \& Sjöberg, K. (1992). Boreal forest-The focal habitats of Fennoscandinavia. In: Ecological principles of nature conservation. Applications in temperate and boreal environments. L. Hansson (Ed.). pp. 252-325. London.

Fang, J., Guo, Z., Hu, H., Kato, T., Muraoka, H., \& Son, Y. (2014). Forest biomass carbon sinks in East Asia, with special reference to the relative contributions of forest expansion and forest growth. Global Change Biology, 20, 2019-2030.

Fernández de Uña, L., Cañellas, I., \& Gea-Izquierdo, G. (2015). Stand competition determines how different tree species will cope with a warming climate. PLoS ONE, 10(3): e0122255

Finat, L., Campana, V. \& Seseña, A. (2000). La ordenación por entresaca en las masas de piñonero de la provincia de Valladolid. In I Simposio del pino piñonero (Pinus pinea L.), Valladolid. Junta de Castilla y León. p. 147 - 157.

Fontes, L., Bontemps, J.-D. Bugmann, H. Van Oijen, M. Gracia, C. Kramer, K. Lindner, M. Rötzer, T.\& Skovsgaard, J. P. 2010. Models for supporting forest management in a changing environment. Forest Systems. 19(SI):8-29

Gracia, C.A., Burriel, J.A., Mata, T., \& Vayreda, J. (2000). Inventari Ecológic i Forestal de Catalunya. Centre de Recerca Ecológica i Aplicacions Forestals.

Hamilton, G.J. (1981). The effects of hight intensity thinning on yield. Forestry, 54. No. 1. 
Hansen, A.J., Spies, T.A., Swanson, F.J., \& Ohmann, J.L. (1991). Conserving biodiversity in managed forests. Lessons from natural forests. BioScience, 41, 292382.

Harmon, M.E., \& Hua, C. (1991). Coarse woody debris in two oldgrowth ecosystems. Comparing a deciduous forest in China and a conifer forests in Oregon. BioScience, 41, 604-610.

Harmon, M.E., Franklin, J.F., Swanson, F.J., Sollins, P., Gregory, S.V., Lattin, J.D., Anderson, N.H., Cline, S.P., Aumen, N.G., Sedell, J.R., Lienkaemper, G.W., Cromack. K. Jr., \& Cummins, K.W. (1986). Ecology of coarse woody debris in temperate ecosystems. Advances in Ecological Research,15, 133-302.

Hart, S.C. (1999). Long-term decomposition of forest detritus in a Mediterranean type climate. In: Abstract Presentations Book of the Blodgett Forest Symposium, Center for Forestry, Berkeley, California, USA.

Hosmer, D.W., \& Lemeshow, S. (1989). Applied Logistic Regression. John Wiley \& Sons, New York, N.Y.

Huang, S., Yang, Y., \& Wang, Y. (2003). A critical look at procedures for validating growth and yield models. In A. Amaro, D. Reed and P. Soares (Eds.), Modelling Forest Systems (pp. 271-293). Wallingford: CABI Publishing.

Hunter, M. L., Jr. (1990). Wildlife, forest, and forestry: Principles for managing forests for biological diversity. Englewood Cliffs, NJ: Prentice-Hall.

Ibañez, J.J., Vayreda, J., \& Gracia, C. (2002). Metodología complementaria al Inventario Forestal Nacional en Catalunya. En: Bravo, F; del Río M.; del Peso, C. (eds.) El Inventario Forestal Nacional: Elemento clave para la gestión forestal sostenible: 6777. Fundación General de la Universidad de Valladolid.

Jandl, R., Lindner, M., Vesterdal, L., Bauwens, B., Baritz, R., Hagedorn, F., Johnson, D.W., Minkkinen, K., \& Byrne, K.A. (2007). How strongly can forest management influence soil carbon sequestration? Geoderma, 137, 253-268.

Jordan, L., Clark III, A., Schimleck, L.R., Hall, D.B., \& Daniels, R.F. (2008) Regional variation in wood specific gravity of planted loblolly pine in the United States. Canadian Journal of Forest Research, 38, 698-710.

Jurgensen, M., Tarpey, R., Pickens, J., Kolka, R., \& Palik, B. (2012) Long-term effect of silvicultural thinnings on soil carbon and nitrogen pools. Soil Science Society of America Journal, 76, 1418-1425.Kaipainen, T.,

Liski, J., Pussinen, A., \& Karjalainen, T. (2004). Managing carbon sinks by changing rotation length in European forests. Environmental Science \& Policy, 7, 205-219.

Keeton, W.S., Franklin, J.F. (2005). Do Remnant Old-Growth Trees Accelerate Rates Of Succession In Mature Douglas-Fir Forests? Ecological Monographs, 75, 103-118. 
Kimmins, H., Blanco, J. A. Seely, B. Welham, C. \& K. Scoullar. 2010. Forecasting forest futures. A hybrid modelling approach to the assessment of sustainability of forest ecosystems and their values. Earthscan Ltd, London. 281 p. p.

Kolari, P., Pumpanen, J., Rannik, U., Ilvesniemi, H., Hari, P., \& Berninger, F. (2004). Carbon balance of different aged Scots pine forests in Southern Finland. Global Change Biology, 10, 1106-1119.

Landsberg, J., \& Sands, P. (2011). Physiological ecology of forest production. Principles, processess and models. First Edit. Elsevier Inc., London, Amsterdam, Burlington, San Diego. 331 p.

Landsberg, J. J., \& Waring, R. H. (1997). A generalised model of forest productivity using simplified concepts of radiation-use efficiency, carbon balance and partitioning. Forest Ecology and management, 95(3),209-228.

Linares, J.C., Delgado-Huertas, A., Camarero, J.J., Merino, J. \& Carreira, J.A. (2009). Competition and drought limit the response of water-use efficiency to rising atmospheric carbon dioxide in the Mediterranean fir Abies pinsapo. Oecologia, 161, 611-624.

Liski, J., Pussinen, A., Pingoud, K., Mäkipää, R., \& Karjalainen, T. (2004). Which rotation length is favourable to carbon sequestration? Canadian Journal of Forest Research, 31, 2004-2013.

MAGRAMA (2013). Cambio climatic: Bases físicas. Guía resumida del quinto informe de evalaución del IPCC. Grupo de Trabajo I. Ministerio de Agricultura, Alimentación y Medio Ambiente, Fundación Biodiversidad y Oficina Española de Cambio Climático, Madrid 44 p.

Martín-Benito, D., Río, M., \& Cañellas, I. (2010a). Black pine (Pinus nigra Arn.) growth divergence along a latitudinal gradient in Western Mediterranean mountains. Annals of Forest Science, 67, 401.

Martín-Benito, D., Río, M., Heinrich, H., Helle, G., \& Cañellas, I. (2010b). Response of climate-growth relationships and water use efficiency to thinning in a Pinus nigra afforestation. Forest Ecology and Management, 259, 967-975.

McComn, W., \& Lindenmayer, D. (1999). Dying, dead, and down trees. In: Maintaining Biodiversity in Forest Ecosystems. Edited by Malcon, L., \& Hunter, J.R., Cambridge University Press, 335-372 pp.

Mokany, K., Raison, R.J., \& Prokushkin, A.S. (2006). Critical analysis of root: shoot ratios in terrestrial biomes. Global Change Biology, 12, 84-96.

Montero, G., Cañadas, N., Yagüe, S., Bachiller, A., Calama, R., Garriga, E., \& Cañellas, I. (2003). Aportaciones al conocimiento de las masas de Pinus pinea L. en los Montes de Hoyo de Pinares (Ávila - España). Revista Montes, 73, 30-40. 
Montero, G., Ruiz-Peinado, R., \& Muñoz, M. (2005). Producción de Biomasa y fijación de $\mathrm{CO}_{2}$ por los bosques españoles. Monografías INIA: Serie Forestal, nº13. 270 pp.

Montero, G., \& Serrada, R. (2013). La situación de los bosques y el sector forestal en España - ISFE 2013. Edit. Sociedad Española de Ciencias Forestales. Lourizán (Pontevedra).

Montes, F., \& Cañellas, I. (2006). Modelling coarse woody debris dynamics in evenaged Scots pine forests. Forest Ecology and Management, 221, 220-232.

Moreno-Fernández, D., Díaz-Pinés, E., Barbeito, I., Sánchez-González, M., Montes, F., Rubio, A., \& Cañellas, I. (2015). Temporal carbon dynamics over the rotation period of two alternative management systems in Mediterranean mountain Scots pine forests. Forest Ecology and Management, 348, 186-195.

Nave, L.E., Vance, E.D., Swanston, C.W., \& Curtis, P.S. (2010). Harvest impacts on soil carbon storage in temperate forests. Forest Ecology and Management, 259, 857-866.

Ninyerola, M., Pons, X., \& Rour, J.M. (2005). Atlas climático digital de la Península Ibérica. Metodología y aplicaciones en bioclimatología o geobotánica. ISBN 9325608-7. Universidad Autónoma de Barcelona, Bellaterra.

Oria de Rueda, J.A., Díez, J., \& Rodríguez, M. (1996). Guía de las plantas silvestres de Palencia. Palencia. Ed. Cálamo, 335 pp.

Pohjola, J., \& Valsta, L. (2006). Carbon credits and management of Scots pine and Norway spruce stands in Finland. Forest Policy and Economics, 9(7), 789-798.

Powers, M.D., Kolka, R.K., Bradford, J.B., Palik, B.J., Fraver, S., \& Jurgensen, M.F. (2012). Carbon stocks across a chronosequence of thinned and unmanaged red pine (Pinus resinosa) stands. Ecological Applications, 22, 1297-1307.

Prestzsch, H. (2002). Grundlagen der Waldwachstumsforschung. München. Parey Verlag.

Pretzsch, H., Biber, P., Schutze, G., Uhl, E., \& Rotzer, T. (2014). Forest Stand Growth Dynamics in Central Europe Have Accelerated since 1870. Nature Communications, 5, 1-10.

Río, M., Calama, R., Montes, F., \& Montero, G. (2003). Influence of competition and structural diversity on basal area growth in uneven-aged stands of stone pine (Pinus pinea L.) in Spain. In: Uneven-aged Forest Management: Alternative Forms, Practices and Constraints. IUFRO- Congress. Helsinki (Finlandia), June 2003.

Río, M., Calama, R., Cañellas, I., Roig, I., Montero, G. 2008. Thinning intensity and growth response in SW-European Scots pine stands. Ann. For. Sci. 65:308-398. 
Río, M., Rodríguez-Alonso, J., Bravo-Oviedo, A., Ruiz-Peinado, R., Cañellas, I., \& Gutiérrez, E. 2014. Aleppo pine vulnerability to climate stress is independent of site productivity of forest stands in southeastern Spain. Trees, 28 (4), 1209-1224.

Roig, S., Río, M., Cañellas, I., \& Montero, G. (2005). Litter fall in Mediterranean Pinus pinaster Ait. stands under different thinning regimes. Forest Ecology Management, 206, 179-190.

Ruíz-Peinado, R., Río, M., \& Montero, G. (2011). New models for estimating the carbon sink capacity of Spanish softwood species. Forest Systems 20(1), 176-188.

Ruiz-Peinado, R., Montero, G., Río, M. (2012) Biomass models to estimate carbon stocks for hardwood tree species. Forest Systems 21, 42-52.

Ruíz-Peinado, R., Bravo-Oviedo, A., López-Senespleda, E., Montero, G., \& Río, M. (2013). Do thinnings influence biomass and soil carbon stocks in Mediterranean maritime pinewoods? European Journal of Forest Research 132, 253-262.

Ruíz-Peinado, R., Bravo-Oviedo, A., Montero, G., \& Río, M. (2014). Carbon stocks in a Scots pine afforestation under different thinning intensities management. Mitigation and Adaptation Strategies for Global Change, doi:10.1007/s11027-014-9585-0

Sands, P. J. (2004). Adaptation of 3PG to novel species: Guidelines for data collection and parameter assignment. Hobart, Australia.

SAS, Sas Institute Inc. (2001). SAS/STATTM User’s Guide, Relase 8.2, Cary, N.C. USA.

Scarascia-Mugnozza, G., Oswald, H., Piussi, P., \& Radoglou, K. (2000). Forest of the Mediterranean region: gaps in knowledge and research needs. Forest Ecology and Management, 132, 97-109.

Schroeder, P., Brown, S., Mo, J., Birdsey, R., \& Cieszewski, C. (1997). Biomass estimation for temperate broadleaf forests of the United States using inventory data. For. Sci., 43, 424-434.

SECF, (2010). Informe de Situación de los bosques y del Sector Forestal en España. Madrid

Siitonen, J., Martikainen, P., Punttila, P., \& Rauh, J. (2000). Coarse woody debris and stand characteristics in mature managed and old-growth boreal mesic forests in southern Finland. Forest Ecology and Management, 128, 211-225.

Smith, D.M., Larsen, B.C., Kelty, M.J., \&Ashton, P.M.S. (1997). The practice of silviculture: Applied forest ecology, 9th Ed. John Wiley and Sons, New York. 537 p.

Sollins, P. (1982). Input and decay of coarse woody debris in coniferous stands in western Oregon and Washington. Canadian Journal of Forest Research, 12: 18-28. 
Somogyi, Z., Cienciala, E., Mäkipää, R., Muukkonen, P., Lehtonen, A., \& Weiss, P., (2007) Indirect methods of large-scale forest biomass estimation. European Journal of Forest Research, 126: 197-207

Spies, T.A., Franklin, J.F., \& Thomas, T.B. (1988). Coarse woody debris in douglas-fir forests of western Oregon and Washington. Ecology, 69, 1689-1702.

Stephens, S.L., \& Moghaddas, J.J. (2005). Fuel treatment effects on snags and coarse woody debris in a Sierra Nevada mixed conifer forest. Forest Ecology and Management, 214, 53-64.

Teobaldelli, M., Somogyi, Z., Migliavacca, M., \& Usoltsev, V.A. (2009). Generalized functions of biomass expansion factors for conifers and broadleaved by stand age, growing stock and site index. Forest Ecology and Management, 257, 1004-1013.

Van Vuuren, D. P., Edmonds, J., Kainuma, M., Riahi, K., Thomson, A., Hibbard, K., Hurtt, G.C. et al. 2011. The representative concentration pathways: an overview. Climatic Change, 109(1-2), 5-31.

Van Wagner, C.E. 1968. The line-intersect method in forest fuel sampling. Forest Science. 14: 20-26.

Vayreda, J., Martínez-Vilalta, J., Gracia, M., \& Retana J. (2012) Recent climate changes interact with stand structure and management to determine changes in tree carbon stocks in Spanish forests. Global Change Biology 18, 1028-1041.

Vesterdal, L., Clarke, N., Sigurdsson, B.D., \& Gundersen, P. (2013). Do tree species influence soil carbon stocks in temperate and boreal forests? Forest Ecology and Management, 309: 4-18.

Warren, W.G., \& Olsen, P.F. (1964). A line-intersect technique for assessing logging waste. Forest Science, 10, 267-276.

Woldendorp, G., Keenan, R.J., Barry, S., \& Spencer, R.D. (2004). Analysis of samplig methods for coarse woody debris. Forest Ecology and Management, 198, 133-148.

Woodall, C.W., Heath, L.S., \& Smith, J.E. (2008). National inventories of down and dead woody material forest carbon stocks in the United States: Challenges and opportunities. Forest Ecology and Management, 256, 221-228.

Woollons, R.C. (1998). Even-aged stand mortality estimation through a two-step regression process. Forest Ecology and Management, 105, 189-195.

Wright, L., 2006. Worldwide commercial development of bioenergy with a focus on energy crop-based projects. Biomass and Bioenergy, 30, 706-714.

Zhang, S., Amateis, R.L., \& Burkhart, H.E. (1997). Constraining individual tree diameter increment and survival models for loblolly pine plantations. Forest Sci., 43, 414-423. 
